\title{
Intracranial Giant Tuberculoma Mimicking Brain Tumor: A Case Report
}

\author{
Beyin Tümörünü Taklit Eden Intrakranial Dev Tüberkülom: \\ Bir Olgu Sunumu
}

\author{
Sua SUMER ${ }^{1}$, Ender KOKTEKIR², Nazlim AKTUG DEMIR ${ }^{1}$, Gokhan AKDEMIR² \\ ${ }_{1}^{1}$ Selcuk University, School of Medicine, Department of Infectious Disease and Clinical Microbiology, Konya, Turkey \\ 2 Selcuk University, School of Medicine, Department of Neurosurgery, Konya, Turkey
}

Corresponding Author: Sua SUMER / E-mail: suasumer@gmail.com

\begin{abstract}
Tuberculomas are small tumor-like lumps that can be seen, usually in large numbers, in central nervous system involvement of tuberculosis. Giant tuberculomas that are big enough to cause symptoms of compression are also encountered, though rarely. When they are really large, tuberculomas may result in increased intracranial compression, neurologic deficits, or epileptic attacks. Giant tuberculomas may be confused with brain tumors on cranial magnetic resonance imaging. Cranial magnetic resonance imaging and histopathology examinations are used for diagnosis. Although magnetic resonance imaging is useful for diagnosing tuberculoma, histopathology examination is the gold standard for a final diagnosis. This paper presents a case involving a 66-year-old patient who complained of headache, imbalance and dizziness, and underwent an operation in the neurosurgery clinic with a pre-diagnosis of brain tumor, and was then diagnosed with intracranial giant tuberculoma.
\end{abstract}

KEYWORDS: Brain tumor, Giant tuberculoma, Tuberculosis

öz

Tüberkülomlar, tüberkülozun santral sinir sistemi tutulumunda görülebilen, genellikle çok sayıda, küçük tümör benzeri kitlelerdir. Nadiren bası semptomlarına neden olacak kadar büyük dev tüberkülomlara da rastlanabilir. Tüberkülomlar, çok büyük oldukları zaman kafa içi basınç artışı, nörolojik defisitler veya epilepsi nöbetlerine neden olabilir. Dev tüberkülomlar, kranial manyetik rezonans görüntülemede beyin tümörleri ile karışabilir. Tanıda kranial manyetik rezonans görüntüleme (MRG) ve histopatolojik incelemeler kullanılır. MRG tüberkülom tanısında faydalı olmakla birlikte, histopatolojik inceleme kesin tanı için altın standarttır. Makalede 66 yaşında baş ağrısı, dengesizlik ve baş dönmesi şikayeti ile başvuran, beyin ve sinir cerrahisi kliniğinde beyin tümörü ön tanısıla opere edilen ve intrakranial dev tüberkülom tanısı alan bir olgu sunulmuştur.

ANAHTAR SÖZCÜKLER: Beyin tümörü, Dev tüberkülom, Tüberküloz

\section{INTRODUCTION}

Tuberculosis is an infectious disease that is frequently seen in developing countries and continues to threaten people's health (10). Central nervous system (CNS) involvement such as meningitis, solitary tuberculoma, abscess, infarct, or miliary parenchymal lesion is seen in approximately $5-10 \%$ of tuberculosis cases (5). Intracranial tuberculomas are tumorlike lumps generated by the tuberculosis granulation tissue in the brain parenchyma, and are seen more rarely than other types of tuberculosis (10). When they are very big, tuberculomas may result in nonspecific neurologic deficits associated with increased intracranial compression, local compression-related neurologic findings, or epileptic attacks. Single, large tuberculomas are often confused with brain tumors in patients who have no accompanying symptoms of infection (7).

This paper presents a case who had an operation with a prediagnosis of brain tumor, was found to have indications of tuberculoma after the pathological examination, and was then diagnosed with intracranial giant tuberculoma.

\section{CASE REPORT}

A 66 year-old male patient who had been suffering from headache, weight loss and weakness for six months presented to the outpatient brain surgery clinic about 20 days after he also experienced imbalance and dizziness. A neurological examination of the patient revealed cerebellar ataxia, right-side dysmetria and dysdiadochokinesis, and nystagmus when looking to the right. In laboratory tests, the patient's erythrocyte sedimentation speed was $61 \mathrm{~mm} /$ $\mathrm{sec}$ and his other hematologic and biochemical tests were normal. Cranial magnetic resonance imaging (MRI) revealed a lump lesion of $4 \times 2.5 \mathrm{~cm}$ in his right cerebellar hemisphere, which had vasogenic edema around it and showed peripheral contrast enhancement after the administration of an intravenous contrast substance; in addition, there was a nodular lesion of $5 \mathrm{~mm}$ in diameter in his left cerebellar 
hemisphere (Figure 1), which was similar in nature and did not form any visible edema. The patient was hospitalized in the brain surgery clinic and scheduled for operation with a pre-diagnosis of brain tumor. Under general anesthesia, the solid pale yellow lump was totally excised from the right cerebellar hemisphere through a right suboccipital craniotomy. Since granulomatous inflammation was detected during the histopathologic examination of the lesion, the patient was assessed by the infectious diseases and clinical microbiology departments. Examinations were made first for tuberculosis and then for sarcoidosis, granulomatous diseases, toxoplasma and fungal infections. In examinations carried out for differential diagnosis, lymphadenopathies were found during whole body screening with positron emission tomography (PET CT) in bilateral, cervical, supraclavicular, mediastinal, intraabdominal, left parailiac, and left inguinal regions. One of the lymphadenopathies in the cervical region was excised for diagnosis and sent for histopathologic and microbiological examination. Granulomatous inflammation was detected during the histopathologic examination of the lymphadenopathy, and DNA-positive tuberculosis was found during its microbiological examination with polymerase chain reaction (PCR). Diagnosed with tuberculosis lymphadenitis and intracranial tuberculoma, the patient was transferred to the infectious diseases and clinical microbiology unit. A quadruple anti-tuberculosis treatment consisting of isoniazid $1 \times 300 \mathrm{mg}$, rifampicin 1x600 mg, pyrazinamide 1×2 $\mathrm{g}$, and ethambutol $1 \times 1500 \mathrm{mg}$ was initiated. A recovery of the general condition of the patient was observed during treatment. In the second month of treatment, the patient's imbalance and neurological symptoms improved. His erythrocyte sedimentation speed was $20 \mathrm{~mm} / \mathrm{sec}$. After administering the quadruple treatment for the first two months, a dual treatment (isoniazid and rifampicin) was started. Monitoring of the patient, who is in the fourth month of treatment, still continues. Shrinkage was seen in the $5 \mathrm{~mm}$ tuberculoma in the left cerebellum at the repeated cranial $\mathrm{MRI}$, and in lymphadenopathies that were present all over the body during PET screening.

\section{DISCUSSION}

Although tuberculosis is primarily an infectious disease that progresses with lung involvement, it can affect many organs and systems (12). Tuberculomas are usually small tumor-like lumps in large quantities, which can be seen in all organs. Intracranial tuberculomas are mostly seen in the basal section of the brain. Major gross features of tuberculomas are small round or oval shaped nodules, ranging from 2 to $12 \mathrm{~mm}$ in size (3). Giant tuberculomas large enough to cause compression symptoms can also be encountered, though rarely $(5,11)$. There are just a few case reports on intracranial giant tuberculomas in the literature $(1,2,6,8,9)$.

These tuberculomas may show various clinical symptoms depending on their location and size. The most frequently seen symptoms include headache, epileptic attacks, neurological deficits, and papilledema $(2,8,9)$. This patient,

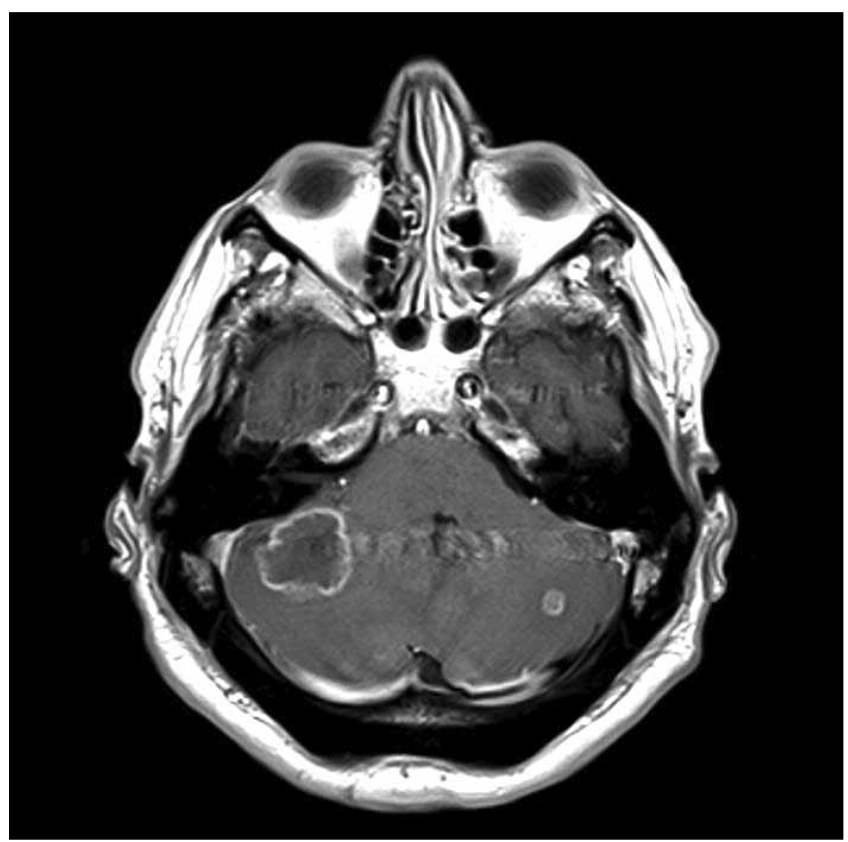

Figure 1: Lump lesion of $4 \times 2.5 \mathrm{~cm}$ in the right cerebellar hemisphere, which has a vasogenic edema around it and shows peripheral contrast enhancement in cranial MRI, and a nodular lesion of $5 \mathrm{~mm}$ in diameter in the left cerebellar hemisphere that is of similar nature with no visible edema.

who had 2 tuberculomas in his cerebellum, one being $4 \times 2.5$ $\mathrm{cm}$ in size, complained of headache and imbalance associated with their compression effect.

Giant tuberculomas in the CNS may be confused with tumoral lesions $(2,8,9)$. Cranial MRI and histopathologic examinations are used for diagnosis. The noncaseating granulomas are usually hypointense on T1-weighted images and hyperintense on T2-weighted images, with homogenous contrast enhancement. The caseating solid granulomas, on the other hand, are relatively isointense or hypointense on T1- and T2-weighted images (9). Although MRI is useful for diagnosing tuberculoma, histopathologic examination is the gold standard for a final diagnosis $(4,9)$. Sarcoidosis, granulomatous diseases, toxoplasma, neoplasms, metastatic lesions, and fungal infections should be considered for the differential diagnosis of intracranial tuberculomas $(4,10)$. The patient's cranial MRI revealed a lump lesion of $4 \times 2.5 \mathrm{~cm}$ in size in his right cerebellar hemisphere; it had vasogenic edema around it and showed contrast enhancement. A nodular lesion of $5 \mathrm{~mm}$ in diameter, which was of a similar nature, was found in his left cerebellar hemisphere. Granulomatous inflammation was detected during the histopathologic examination of the lesion. During the investigations to obtain a differential diagnosis; sarcoidosis, granulomatous diseases, toxoplasma, and fungal infections were evaluated.

From these lesions, Mycobacterium tuberculosis can be shown using the culturing or PCR method (3). Since the patient was operated with a pre-diagnosis of brain tumor, the 
lump that was removed from cerebellum was subjected only to a histopathologic examination. When the histopathologic result indicated tuberculosis, screening was carried out during which cervical lymphadenopathy was detected, and the microbiological examination of this revealed Tbc DNA positivity.

Early diagnosis and correct treatment are important in this disease in terms of reducing mortality and morbidity $(5,11)$. A primary treatment method is the medical approach and surgery is not usually recommended. For the form of tuberculosis that progresses with CNS involvement, quadruple treatment is recommended for the first two months and then a dual anti-tuberculosis treatment should be completed in 9-12 months. While clinical recovery takes place within a few weeks, radiological shrinkage or elimination of lesions lasts from 6-12 months (7). A quadruple anti-tuberculosis treatment consisting of rifampicin, ethambutol, isoniazid, and pyrazinamide was initiated for our patient. In the second month of treatment, the patient's imbalance and neurological symptoms improved. After administering the quadruple anti-tuberculosis treatment for the first two months, dual treatment (isoniazid and rifampicin) was started. Monitoring of the patient, who is in the fourth month of treatment, still continues. Shrinkage was seen in the $5 \mathrm{~mm}$ tuberculoma in the left cerebellum at the repeated cranial MRI, and in lymphadenopathies that were present all over the body during PET screening.

In conclusion, in regions where tuberculosis is endemic as in our country, tuberculomas should be considered in the differential diagnosis of lesions that occupy space in the CNS.

\section{REFERENCES}

1. Álvarez-Salgado JA, Ruiz-Ginés JA, Fuentes-Ventura CD, Gonzales-Sejas AG, Belinchón de Diego JM, GonzálezLlanos Fernández de Mesa F, Rodríguez de Lope-Llorca A: Intracranial tuberculoma simulating a malignant tumor: Case report and literature review. Neurocirugia (Astur) 22(6): 600604,2011
2. Aniba K, Ghannane $H$, Jalal $H$, Belhaj $Z$, Ousehal A, Lmejjati M, Benali SA: Giant cerebellar tuberculoma mimicking a malignant tumor. Neurochirurgie 55(3): 337-339, 2009

3. Bayindir C, Mete O, Bilgic B: Retrospective study of 23 pathologically proven cases of central nervous system tuberculomas. Clin Neurol Neurosurg 108(4): 353-357, 2006

4. Bernaerts A, Vanhoenacker FM, Parizel PM, Van Goethem JW, Van Altena R, Laridon A, De Roeck J, Coeman V, De Schepper AM: Tuberculosis of the central nervous system: Overview of neuroradiological findings. Eur Radiol 13(8):1876-1890, 2003

5. Ertem DH, Aslan ND, Altunkaynak Y, Yıldız DS, Baybaş S: İzole beyin sapı tüberkülomu. J Psychiatry Neuro Sci 23(4):288-292, 2010

6. Guillén-Quesada A, García-Armengol R, Pérez-Muñoz N, Gargallo E, García-García JJ, Costa-Clara JM: Intracranial tuberculoma: A case report and review of the literature. Rev Neurol 47(12): 631-634, 2008

7. Keklikoğlu HD, Çoruh Y, Yoldaş TK, Keskin S: Central nervous system tuberculoma and Pott's disease: Case report. J Neurol Sci 25(2):142-147, 2008

8. Parihar V, Yadav YR, Sharma D: Giant extra-axial posterior fossa tuberculoma in a three-year-old child. Neurol India 57(2): 218-220, 2009

9. Poonnoose SI, Singh S, Rajshekhar V: Giant cerebellar tuberculoma mimicking a malignant tumour. Neuroradiology 46(2):139-139, 2004

10. Sonmez G, Ozturk E, Sildiroglu HO, Mutlu H, Cuce F, Senol MG, Kutlu A, Basekim CC, Kizilkaya E: MRI findings of intracranial tuberculomas. Clin Imaging 32(2): 88-92, 2008

11. Talamás O, Del Brutto OH, García-Ramos G: Brain-stem tuberculoma. An analysis of 11 patients. Arch Neurol 46(5): 529-535, 1989

12. Wasay M: Central nervous system tuberculosis and paradoxical response. South Med J 99(4): 331-332, 2006 